Magda Wielgus*

\title{
Wykorzystanie kreatywności w komunikacji marketingowej marek w mediach społecznościowych
}

Streszczenie: Celem rozdziału jest pokazanie wpływu wykorzystania kreatywności w komunikacji marketingowej marek w mediach społecznościowych. Został on zrealizowany poprzez analizę wybranych przykładów kampanii realizowanych w mediach społecznościowych, wyróżniających się oryginalnością, dużym zainteresowaniem odbiorców oraz pozytywną oceną ekspertów.

Słowa kluczowe: komunikacja marketingowa, kreatywność, marka, media społecznościowe, marketing, Facebook, Instagram, YouTube.

\section{Wstęp}

Przedsiębiorstwo, by mogło realizować swój podstawowy cel działalności, jakim jest osiągnięcie zysku, musi aktywnie komunikować się z otoczeniem. Jednym z podstawowych narzędzi takiej komunikacji są działania marketingowe. W dynamicznie zmieniającym się środowisku biznesowym firma zmuszona jest do stałej aktualizacji swojej wiedzy i metod dotarcia do konsumenta. W ciągu ostatnich 10 lat w zestawieniu środków dystrybucji treści marketingowej zauważyć można rosnący udział mediów społecznościowych jako kanałów bezpośredniej komunikacji z otoczeniem. Jednakże stale wzrastający odsetek firm włączających platformy społecznościowe do swoich działań promocyjnych doprowadził do wzmożonej konkurencji także i na tym polu. Firmy chcące przyciągnąć uwagę potencjalnego klienta zmuszone są do poszukiwania kreatywnych rozwiązań, które wyróżnią ich komunikat w „morzu” komercyjnych treści, jakie można dziś spotkać w mediach społecznościowych.

* Wydział Nauk o Wychowaniu, Uniwersytet Łódzki. 
Celem niniejszej pracy jest zbadanie wpływu wykorzystania kreatywności w komunikacji marketingowej marki w mediach społecznościowych. W celu uzyskania niezbędnych ku temu informacji przeprowadzone zostały badania w formie wywiadów eksperckich.

\section{Zmiany w komunikacji marketingowej marek}

Obserwując kierunek rozwoju współczesnego marketingu, można zauważyć, że coraz większe znaczenie zyskują koncepcje tzw. marketingu partnerskiego, interakcyjnego, czy też marketingu relacyjnego [Sagan, 2013: 15-16]. To, co łączy wymienione koncepcje to przede wszystkim założenie budowania i utrzymania trwałych związków pomiędzy firmą a klientem, który znajduje się $\mathrm{w}$ centrum zainteresowania [Bdoń, https://freshmail.pl/blog/marketing-relacji-co-jest-jak-go-stosowac/ (dostęp: 12.02.2019)]. Takie podejście ma zatem przynieść korzyści nie tylko przedsiębiorstwu, ale i samemu konsumentowi. Modyfikacja nastawienia organizacji do klienta jest wynikiem zmian, jakie zaszły w otoczeniu marketingowym przedsiębiorstw i wiąże się przede wszystkim [Pizło, http://www.wne.sggw.pl/czasopisma/pdf/EIOGZ_2008_nr69_s89.pdf (dostęp: 1.02.2019)]:

- ze zmniejszeniem lojalności konsumentów wobec marek produktów,

- ze wzrostem wymagań wobec produktu i oczekiwaniem wysokiego poziomu obsługi klienta,

- $\mathrm{z}$ wysokimi kosztami marketingu transakcyjnego,

- z globalizacją marketingu,

- $\mathrm{z}$ coraz większą wrażliwością konsumentów na ceny,

- z rozwojem technologii informatycznej i powstawaniem kanałów umożliwiających bardziej osobistą komunikację z konsumentami i budowaniem relacji z nimi.

Głównymi celami współczesnego marketingu jest zatem odejście od postrzegania nabywców jako homogenicznej grupy i podjęcie próby zaspokojenia indywidualnych potrzeb konsumentów lub społeczności. Jest to wyraźny przejaw przejścia z kultury produktu do kultury konsumenta i traktowania go jako partnera procesu. 


\section{Zbliżenie konsumenta do marek za sprawą internetu i mediów społecznościowych}

Zanim rozwinął się marketing partnerski, musiały pojawić się nowe rozwiązania oferujące możliwość bliższego i bardziej bezpośredniego kontaktu z klientem niż było to w marketingu tradycyjnym. Takim środowiskiem stał się internet i media społecznościowe.

Druga połowa lat dziewięćdziesiątych XX wieku uznawana jest za okres dynamicznego rozwoju zarówno internetu, jak i marketingu online. Głównymi formatami reklamowymi stały się wówczas banery, mailingi (czyli systematycznie wysyłane wiadomości $e$-mail do potencjalnych lub już obecnych klientów), reklamy typu pop-up/pop-under (nowe okno, które otwiera się przed/za obecnym, wyświetlając reklamy lub całą stronę internetową [Leśniewska, 2006: 53], czy toplayer (animacja realizowana na przezroczystej warstwie nałożonej na serwis w przeglądarce internetowej [https://pl.wikipedia.org/wiki/Toplayer (dostęp: 29.01.2019)]). Obecnie mamy do czynienia z wieloma nowymi formatami reklamowymi, a przekaz wyświetlanych treści jest personalizowany i dostosowywany do klienta i jego zainteresowań. Informacje te zbierane są przez programy śledzące naszą działalność w sieci i podejmowane przez nas wyszukiwania.

Przez lata zmieniły się nie tylko same możliwości internetu, a także sposób korzystania z niego. Kaznowski zauważa, że od 2000 roku zaszła dwukrotna zmiana modelu korzystania z sieci. Co więcej podaje, że jest to zawsze wynikiem dwóch czynników:

- wzrostu doświadczenia internautów,

- zmianą technologiczną w zakresie narzędzi oferowanych w sieci [Kaznowski, 2016: 82].

Obyci po kilku latach z wirtualną przestrzenią internauci, rozumiejący jej mechanizm działania i możliwości, coraz częściej zaczęli komunikować się ze sobą nawzajem na różnych forach i portalach wymieniając się swoją wiedzą, doświadczeniami i tworząc swoją wspólną przestrzeń w sieci. Działania te stały się podłożem do rozwoju mediów społecznościowych.

Słownik Języka Polskiego definiuje media społecznościowe jako ,technologie internetowe i mobilne, umożliwiające kontakt pomiędzy użytkownikami poprzez wymianę informacji, opinii i wiedzy" [Słownik Języka Polskiego, http://sjp.pwn.pl/slowniki/media\%20spo\%C5\%82eczno\%C5\%9Bciowe.html (dostęp: 20.01.2019)]. Natomiast D. Kaznowski podaje, iż są to ,środki przekazu podlegające społecznej kontroli, które mogą być wykorzystywane na dowolną skalę, zawierające zarówno treści przekazu, jak i możliwe 
punkty widzenia odnoszące się do informacji” [Kaznowski, 2016: 89]. Tomasz Bonek i Marta Smaga podkreślają atrybut społeczny i zaznaczają, że błędnym jest kojarzenie portali społecznościowych jedynie ze stronami, gdzie można tworzyć profile, dodawać zdjęcia i kontaktować się z innymi członkami [Bonek, Smaga, 2013: 13]. Jak piszą „do kategorii mediów społecznościowych należą bowiem wszystkie witryny, których zawartość tworzą użytkownicy, niezależnie od tego, jakim służy ona celom - rozrywce, biznesowi czy edukacji” [Ibidem]. Marcin Żukowski wyróżnia osiem rodzajów mediów społecznościowych, są to m.in.:

- serwisy społecznościowe, np. Facebook, nk.pl,

- mikroblogi, np. Twitter,

- społeczności profesjonalistów, np. LinkedIn,

- portale z zawartością tworzoną, np. Wikipedia, YouTube,

- tematyczne portale społecznościowe, np. Filmweb [Żukowski, 2016: 28].

Dziś do czołówki najpopularniejszych serwisów społecznościowych [Kallas, Top 15 Most Popular Social Networking Sites and Apps, https://www.dreamgrow.com/top-15-most-popular-social-networkingsites/ (dostęp: 29.01.2019)] zaliczamy przede wszystkim Facebooka (założonego w 2004 roku) z liczbą ponad 2 mld użytkowników [Facebook newsroom, https://newsroom.fb.com/company-info/ (dostęp: 28.01.2019)]. Na drugim miejscu jest YouTube [YouTube for press, https://www.youtube.com/intl/en-GB/yt/about/press/ (dostęp: 28.01.2019)] (powstał w 2005 roku) - ponad 1 mld korzystających z platformy. Instagram (w sieci od 2001 roku) może pochwalić się ponad $800 \mathrm{mln}$ aktywnych kont w każdym miesiącu [Dane Instagramu, wrzesień 2019, https://business.instagram.com/?locale=pl_PL (dostęp: 26.01.2019)], Twitter (uruchomiony w 2006 roku) 328 mln użytkownikami [Zephoria Inc, Top 01 Twitter statistic, https://zephoria.com/twitter-statisticstop-ten/ (dostęp: 28.01.2019)], a Snapchat $200 \mathrm{mln}$ [Kallas, https://www.dreamgrow.com/top-15-most-popular-social-networkingsites/ (dostęp: 29.01.2019)].

Rozpoczęcie działań marketingowych w mediach społecznościowych potencjalnie umożliwia zatem marketerom dostęp do prawie $1 / 3$ ludzkości! Co więcej, jak podaje amerykańska agencja marketingowa Mediakix, przeciętny człowiek poświęca na media społecznościowe ponad 5 lat swojego życia [Mediakix Team, How much time we spend on social media, http://mediakix.com/2016/12/how-much-time-is-spent-on-social-medialifetime/\#gs.zah2iPs (dostęp: 28.01.2019)]. YouTube natomiast podaje, że każdego dnia na platformie oglądane jest miliard godzin nagrań video [YouTube for press, https://www.youtube.com/intl/en-GB/yt/about/press/ (dostęp: 27.07.2019)]. Statystyki te uświadomiły firmom działającym na 
rynku, że jeśli chcą pozostać blisko swoich konsumentów, muszą zmienić dotychczasową strategię online marketingową i ukierunkować swoje działania także na platformy społecznościowe. Dziś na Facebooku istnieje ponad 50 mln kont firmowych [Chaykowski, 2015]. Na Instagramie jest ich $15 \mathrm{mln} .80 \%$ kont obserwuje chociaż jedną firmę. Co więcej, z danych wewnętrznych udostępnianych przez Instagram wynika, że $60 \%$ osób korzystających z aplikacji przyznaje, że to właśnie tu dowiaduje się o nowych produktach [Instagram business, https://business.instagram.com/getting-started (dostęp: 28.01.2019)]. Ponadto czas pomiędzy wytworzeniem treści, a jej publikacją ograniczony jest niemalże do minimum. Stanowi to znaczną przewagę nad mediami tradycyjnymi, gdzie zarówno czas od przygotowania do udostępnienia reklam, jak i koszty ich produkcji i wyświetlenia w ramówce telewizyjnej są znacząco większe.

Marketing w mediach społecznościowych jest nie tylko bardziej ekonomiczny, ale także efektywniejszy [Mercer, Traditional vs. Online Marketing. The Real Value of Your Online Marketing Efforts, https://seriouslysimplemarketing.com/traditional-vs-online-marketing/ (dostęp: 29.01.2019)]. Jest to wynikiem dostępnych na platformach narzędzi analitycznych, które pozwalają marketingowcom precyzyjnie wybrać grupę docelową publikowanych treści poprzez zastosowanie odpowiednich filtrów: wieku, lokalizacji, płci, zainteresowań itd. Narzędzia te umożliwiają także badanie skuteczności prowadzonych kampanii dzięki informacjom o liczbie osób, które wyświetliły lub kliknęły na reklamę, czy wydarzenie. Możliwe jest także poznanie poziomu zaangażowania osób odwiedzających profil firmy, który mierzony jest ilością uzyskanych polubień, udostępnień lub komentarzy. Takie precyzyjne statystyki pozwalają na bieżącą poprawę tworzonych materiałów.

Przedsiębiorstwa świadome grupy docelowej swoich produktów/ usług muszą przy wyborze odpowiedniego kanału promocji wziąć również pod uwagę specyfikę poszczególnych platform oraz dane demograficzne dominującej grupy użytkowników odwiedzających wybrany portal społecznościowy. Jak wynika z badań MarketingLand na Facebooku występuje największy przekrój wiekowy użytkowników [Peterson, 2017]. Znajdziemy tu bowiem zarówno nastolatków, jak i osoby po 50 roku życia. YouTube natomiast podaje, że głównymi odbiorcami zamieszczanych na kanałach treści są osoby w wieku od 18 do 34 lat [YouTube for press, https://www.youtube.com/intl/en-GB/yt/about/press/ (dostęp: 18.01.2019)]. Podobnie jest na Instagramie. Natomiast Twitter z racji swojej specyfiki portalu bardziej opiniotwórczego, wykorzystywanego często przez osoby publiczne (m.in. dziennikarzy, polityków, celebrytów) przyciąga głównie osoby dojrzałe. Przeciwieństwem jest 
natomiast Snapchat, który jest zdominowany przez młodsze pokolenia, przeważnie 13-17-latków.

Na rozwój marketingu w mediach społecznościowych wpływ miało wiele czynników. Decydującym impulsem pozwalającym na rozpowszechnienie platform był postęp technologii i dostępności internetu. Stworzenie opcji reklamowych dla firm przez twórców portali dodatkowo napędza ten proces. W przeciwieństwie do marketingu offline świat online dynamicznie się zmienia. Ważna jest stała aktualizacja wiedzy i obecnych trendów, gdyż dostępne narzędzia marketingowe szybko tracą popularność na rzecz nowych. Wielość platform społecznościowych o różnej specyfice i charakterystyce ich użytkowników sprawia, że coraz ważniejsza staje się obserwacja danych. Jak podkreśla M. Sadowski rośnie zapotrzebowanie na osoby wyspecjalizowane w analizie efektywności działań marketingowych, obsłudze klienta w sieci, czy ochronie reputacji online [Sadowski, 2013: 20-23]. Silna konkurencja wymusza na firmach tworzenia przemyślanej i co ważne spójnej strategii marketingowej. Działania online muszą uzupełniać się z inicjatywami podejmowanymi poza internetem. A konsumenci stają się coraz bardziej wymagający i od marek oczekują treści dla nich wartościowych. Nie chcą bowiem czuć się celem perswazyjnych działań marketingowych. Czują, że dzięki mediom społecznościowym mają głos i chcą go wykorzystać. Pragną współtworzyć marki.

\section{Kreatywność w komunikacji marketingowej marek w mediach społecznościowych}

Kreatywność, jako wrodzona cecha każdego człowieka, pozwala ludziom rozwijać się i generować innowacyjne pomysły już od młodzieńczych lat. Wraz z ich upływem pojawia się jednak wiele czynników wpływających na poziom rozkwitu lub spadku umiejętności kreatywnego myślenia. Co więcej T.M. Ambile podaje, że kreatywność każdej jednostki składa się z trzech komponentów, są to: wiedza, umiejętności twórczego myślenia i motywacja [Luecke, Katz, 2005: 124; za Ambile, 1998: 77-87]. Umiejętności twórczego myślenia decydują o tym, jak ludzie reagują w sytuacji, gdy napotykają problem. Jest to sposób, w jaki poszukują rozwiązań oraz poziom otwartości ich umysłu na generowanie nowych pomysłów. Wewnętrzna motywacja ma natomiast za zadanie samoistnie napędzać człowieka do poszukiwania tych rozwiązań. Wewnętrzne pragnienie osiągnięcia sukcesu daje bowiem lepsze efekty i twórcze rozwiązania niż motywacja zewnętrzna. Komponent wiedzy, 
o którym wspominają autorzy, w ich rozumieniu obejmuje wiedzę techniczną, znajomość procedur i kwalifikacje intelektualne [Ibidem].

Uwarunkowaniem sprzyjającym procesowi kreatywnemu w marketingu jest przede wszystkim wiedza o klientach i grupie docelowej, do której dana marka kieruje swoje komunikaty. Dzięki wielopoziomowym statystykom, jakie oferują media społecznościowe, marketerzy są w stanie stworzyć model obserwatora firmowego kanału społecznościowego. Dane o użytkownikach zbierane są na podstawie informacji, które oni sami udostępniają na swoich profilach, a także ich aktywności na nich, wyrażanej poprzez polubienia i obserwacje określonego rodzaju stron. Wiedza o osobach odwiedzających konto marki, zdobyta dzięki analizie danych, pozwala wykreować tzw. buyer personas [Feedink.com, Snajperska precyzja $w$ targetowaniu reklamy na Facebooku, https://feedink.com/pl/target-facebook-ads-like-pro/ (dostęp: 12.04.2019)], czyli model osoby reprezentującej grupę docelową. Dzięki takiemu zabiegowi możliwe jest określenie optymalnych potrzeb i oczekiwań potencjalnego klienta. W zależności od tego jak dokładnie zostaną opisane jego cechy, tak precyzyjna będzie możliwość dostosowania komunikatu marketingowego, budowania zaangażowania klienta w relacji z marką oraz jego identyfikacja z produktem. Na podstawie wyników danych statystycznych można określić dla firmy czy marką interesują się bardziej kobiety, czy mężczyźni. W jakim są wieku i czym się interesują. Jest to dla marketera także informacja o potrzebach takich osób i o obszarach, w których może im pomóc dany produkt. Treści kierowane do ludzi młodych powinny być inne niż te dedykowane do osób dojrzałych wiekowo. Dzieli ich bowiem różnica doświadczeń i problemów, jakie napotykają na co dzień. Inny jest także język komunikatów. Wzięcie pod uwagę tych aspektów jest niezwykle istotne, gdyż mimo że komunikat będzie unikatowy i kreatywny może w ogóle nie zostać zaszczepiony w umyśle odbiorcy. Dla danej grupy odbiorców może być po prostu nieskuteczny.

Niekiedy statystyki mogą być również kompasem wskazującym, że obrany w strategii marketingowej kierunek nie pokrywa się z obecnymi działaniami. Informują, że komunikaty docierają do nieodpowiedniej grupy, co w długofalowym procesie może doprowadzić do stagnacji w wynikach sprzedaży. Daje to marketerom przestrzeń do regularnego modyfikowania i optymalizowania działań w celu uniknięcia strat finansowych.

Kolejnym istotnym zasobem informacji jest znajomość trendów panujących obecnie w sieci. Warto być na bieżąco z informacjami, o tym co aktualnie porusza internautów, o jakich tematach dyskutują, jakie produkty kupują. Taka wiedza może być wykorzystana przez kreatywnych 
marketerów świadomych potęgi real-time marketingu, czyli marketingu czasu rzeczywistego. Głównymi założeniami tej strategii jest szybka i trafna reakcja na niespodziewaną sytuację, wydarzenie czy zachowanie klientów. Media społecznościowe dają tu marketerom możliwość natychmiastowej reakcji, co nie byłoby możliwe poprzez media tradycyjne. Odpowiednie wyczucie sytuacji, i co najważniejsze kreatywne odniesienie jej do marki produktu/firmy, pozwala zdobyć popularność wśród internetowej społeczności, która często sama dzieli się takimi treściami wśród swoich znajomych, udostępniając ciekawy post. W real-time marketingu jest zatem kluczowe, by reagować na informacje, którymi interesują się potencjalni klienci firmy, by treść komunikatu przyciągnęła ich uwagę, a w konsekwencji doprowadziła do wzrostu świadomości marki.

Podczas poszukiwań kreatywnych sposobów komunikacji w mediach społecznościowych warto znać samą specyfikę danego kanału. Różnice występujące między tymi platformami mają bowiem bezpośrednie przełożenie na rodzaj treści, jakie są tam dobrze przyjmowane. Na przykład na Facebooku warto udostępniać kilkudziesięciosekundowe filmiki. Nie sprawdzą się jednak dłuższe kilkunastominutowe video. Facebooka wielu użytkowników odwiedza bowiem na chwilę, by sprawdzić najnowsze wiadomości, ale robią to kilka razy dziennie. Zupełnie inaczej sytuacja wygląda na YouTube, gdzie widzowie lubią oglądać miniseriale, podcasty czy dłuższe nagrania. Dodatkowo ważna jest ogólna demografia użytkowników platformy. Z aplikacji Instagram korzystają w większym stopniu ludzie do 35 roku życia, przy czym na Facebooku goszczą już bardziej zróżnicowane grupy różnych pokoleń. Takie informacje stanowią drogowskaz dla twórców komunikacji marketingowej.

Oprócz tego, kreatywni marketerzy powinni znać różnorodne narzędzia oferowane przez portale. Na Instagramie może to być Instagram Stories, gdzie publikowane treści dostępne są tylko przez 24 godziny. Relacje dnia można natomiast wyróżnić i udostępnić w specjalnym albumie. Innym przykładem funkcjonalności, która szybko została wykorzystana przez marketerów były ankiety przeprowadzane w codziennych relacjach. Swego czasu bardzo popularnym zabiegiem było stosowanie specjalnych filtrów nakładających maski zwierząt na twarz pozującej osoby. Umieszczone zdjęcie wraz z odpowiednim pytaniem i możliwością wyboru odpowiedzi najbliższej odbiorcy pozwalały w łatwy sposób zbadać preferencje konsumentów.

W twórczej działalności przydaje się nie tylko techniczna znajomość mediów społecznościowych, ale i ich uwarunkowania prawne. Jest to często spotykany problem. Przez agencje kreatywne i marketerów tworzone są ciekawe, kreatywne konkursy lub treści mające angażować społeczność, jednakże w ostatecznym rozrachunku okazuje się, że nie mogą 
być one opublikowane ze względu na regulaminy stosowane przez te kanały. Świadomość tych ograniczeń pozwala ukierunkować odpowiednio sposób myślenia i zmusza do kreatywnego poszukiwania rozwiązań.

\section{Przyklady kreatywnych form komunikacji marketingowej}

W środowisku, w którym panują wyrównane możliwości technologiczne przewagą konkurencyjną staje się informacja/wiedza oraz jej efektywne zastosowanie w określonym rozwiązaniu. Kreatywność jest niezwykle ważna $\mathrm{w}$ działaniach na rynkach mocno konkurencyjnych, gdzie tylko twórcze rozwiązania pozwalają wyróżnić się firmom z powszechnego zgiełku informacyjnego. Podobnie wygląda również sytuacja w mediach społecznościowych. Marketerzy przy każdej kampanii walczą o nowych obserwatorów, o zaangażowanie społeczności i przyciągnięcie uwagi internautów. Efekt tych działań jest różny. W tej części pracy przytoczonych zostało kilka kreatywnych kampanii i kreacji marketingowych realizowanych w mediach społecznościowych, które zdobyły powszechne uznanie otrzymując nagrody w branżowych konkursach lub były szeroko rozpowszechniane i omawiane przez specjalistów branży.

Kampania wódki Wyborowej „30/90”, za której realizacją stała Agencja McCann Worldgroup, otrzymała dwie srebrne nagrody w konkursie Mixx Awards 2019. Została doceniona w kategorii Online Marketing with Influencer oraz Social Community Building. Nazwa projektu nawiązuje do podwójnego jubileuszu: 30. urodzin Radzimira Dębskiego pseud. JIMEK, który został zaproszony do współpracy z firmą oraz 90. urodzin marki Wyborowa. Głównym założeniem projektu było stworzenie utworu, którego współtwórcami byliby fani marki i artysty. By tego dokonać Radzimir Dębski na swoich profilach społecznościowych zachęcał internautów do wysyłania video ze specyficznymi, nawet dziwnymi dźwiękami, które kolejno zostaną przez niego skomponowane w jeden oryginalny utwór. Na potrzeby kampanii została stworzona specjalna strona internetowa, na której internauci mogli umieszczać swoje nagrania, a cała akcja była oczywiście szeroko promowana w mediach społecznościowych. Zarówno przez markę, jak i przez samego JIMKA, który podsycał zainteresowanie konkursem publikując kilka swoich interpretacji abstrakcyjnych dźwięków. Także internauci udostępniali swoje melodie i dzielili się nimi ze swoimi znajomymi. Wyniki kampanii 
były imponujące. Liczba osób, która zaangażowała się w projekt zaskoczyła samych twórców. Na stronę wpłynęło 1152 zgłoszeń, spośród których kompozytor wyłonił 196 zwycięzców. Ich nagrania pojawiły się w oficjalnym teledysku do skomponowanego utworu. Dodatkowo wyróżnione osoby zaproszono na specjalny urodzinowy koncert, który stanowił zwieńczenie całego projektu. Wszystkie nadesłane nagrania to łącznie 6,5 godziny tzw. User Generated Content. Cały projekt uzyskał łącznie ponad 143515591 wyświetleń, przerastając oczekiwania marki o 71\%. O marketingowej skuteczności całej akcji świadczy także sprzedaż całego asortymentu 750000 butelek Wyborowej z limitowanej urodzinowej kolekcji, których grafikę także projektował R. Dębski [WYBOROWA Project 30/90, https://www.youtube.com/watch?v=KKMO1xQ-k68 (dostęp: 25.05.2019)]. A warto pamiętać, że Polska jest krajem, gdzie reklamowanie alkoholu jest zabronione.

Najlepszym przykładem dobrego połączenia kreatywności z wiedzą na temat aktualnych wydarzeń kulturalnych, politycznych i społecznych jest Real Time Marketing, czyli marketing czasu rzeczywistego. Założeniem tego sposobu komunikacji marketingowej jest szybkie reagowanie na aktualne i szeroko komentowane wydarzenia. Równie ważna jest także interakcja marki z klientami, którzy wchodzą w komunikację z marką poprzez komentarze czy udostępnienia treści wygenerowanej przez firmę, jeśli jest ona kreatywna, ciekawa i często zabawna. Wiele marek próbowało zyskać rozgłos z wykorzystaniem tej techniki, jednakże nie jest to takie proste. By stworzyć dobrą treść Real-Time Marketingowa wymagana jest bardzo dobra znajomość produktów marki oraz grupy odbiorców komunikatu. Doskonale radzi sobie z tym szwedzka marka mebli - IKEA. Wielokrotnie grafiki firmy pojawiające się w mediach społecznościowych w zabawny sposób komentowały obecne wydarzenia. Co ważne, główną rolę zawsze odgrywał wybrany produkt marki. Jednym z najnowszych przykładów takich działań jest stworzona przy okazji ślubu księcia Harrego i Megan Markle grafika przedstawiającą krzesło o katalogowej nazwie Harry z podpisem Nie martw się, HARRY jest wciaż dostępny [Kuchta, 2017] (rysunek 1).

Nieco wcześniej marka odniosła się także do sprzedanego za rekordową cenę $450 \mathrm{mln}$ dolarów obrazu Leonardo da Vinci i zestawiła to wydarzenie z reklamą ramek i opraw do obrazów (rysunek 2). 
Rysunek 1. IKEA. Real-time marketing: Ślub księcia Harrego

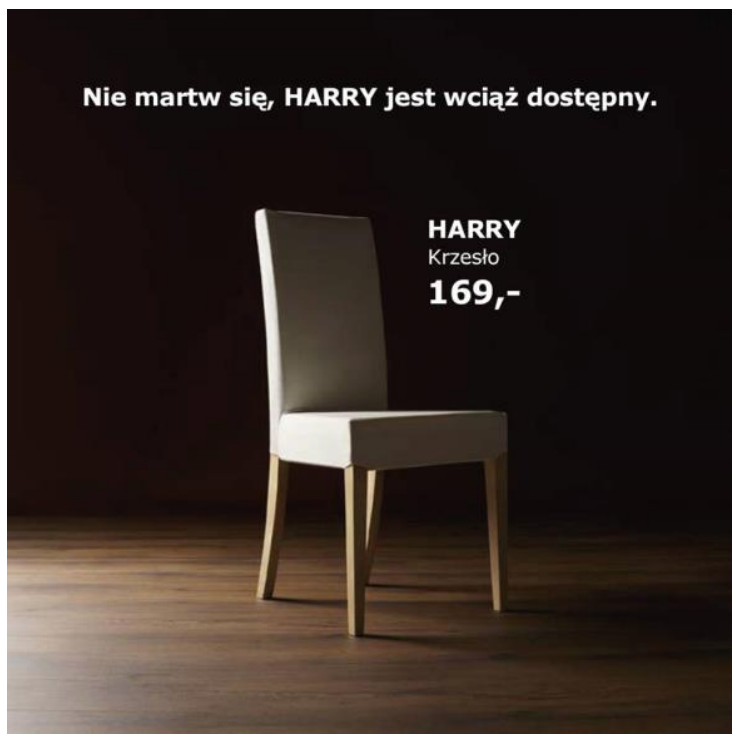

Źródło: Facebook Ikea, https://bit.ly/2N4OfWE (dostęp: 13.06.2019).

Rysunek 2. IKEA. Real-time marketing: Leonardo da Vinci

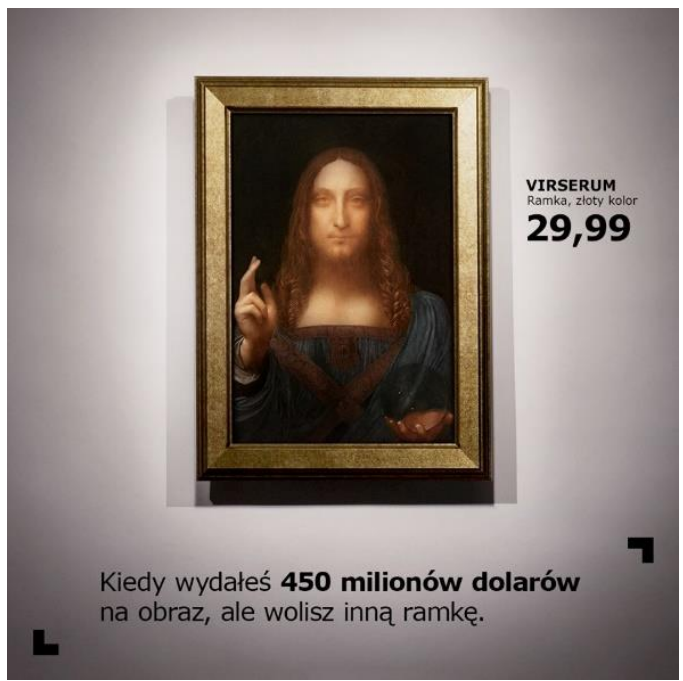

Źródło: Facebook Ikea, https://bit.ly/2KuTuAs (dostęp: 13.06.2019). 
Czasem szum wokół produktu firmy powstaje niespodziewanie i potrafi zaskoczyć nawet ją samą. Tak stało się np. z kakao DecoMorreno po jednym z postów internautki zamieszczonym na portalu Facebook, gdzie w zamkniętej grupie zapytała, czy ktoś zna więcej książek tego autora (zamieszczając pod postem zdjęcie opakowania Cacao DecoMorreno). Kopie tej wiadomości zaczęły szybko rozprzestrzeniać się także poza grupą. Na portalu Lubimyczytać.pl pojawiła się książka Najwyższa jakość autorstwa Cacao DecoMorreno, a internauci zaczęli spontanicznie udzielać recenzji tej pozycji. Dział marketingu DecoMorreno postanowił wykorzystać ogromny rozgłos wokół marki oraz wykorzystać kreatywne wariancje z opakowaniem kakao i zorganizował na profilu marki konkurs na fabułę książki (rysunek 3). Do tej pory panują wątpliwości, czy cała akcja nie była od początku zaplanowaną kampanią marketingową, czy uzyskany rozgłos jest faktycznie kwestią przypadku i odpowiedniej, szybkiej reakcji firmy na wydarzenia w sieci.

Rysunek 3. Cacao DecoMorreno
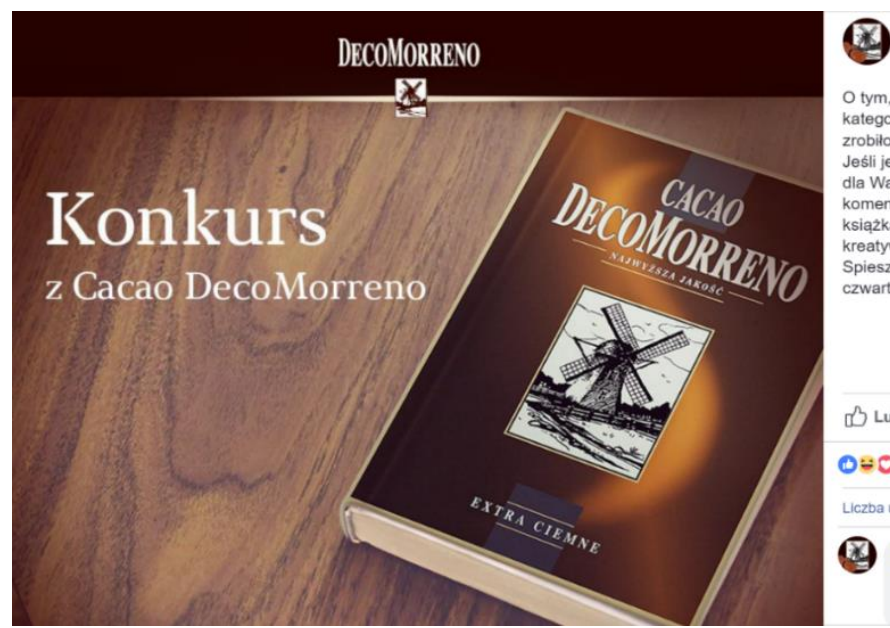

DecoMorreno

Polub stronę - 8 czerwca 2016 - $€$

O tym, że Cacao DecoMorreno to maestro w swojej kategorii, wie już chyba każdy $\because$ W ostatnim czasie zrobiło się o nim jeszcze głośniej, co bardzo cieszy. Jeśli jesteście fanami Cacao DecoMorreno, mamy dla Was konkurs! Uruchomcie fantazję i napiszcie w komentarzu, o czym według Was mogłaby być ksiązka „Najwyższa jakośc". Trzy najbardzie kreatywne odpowiedzi odpowiednio nagrodzimy $;$ Spieszcie się. Czas macie jedynie do jutra, tj. do czwartku 9.06, do godziny 23:59. Powodzenia! $\Theta$

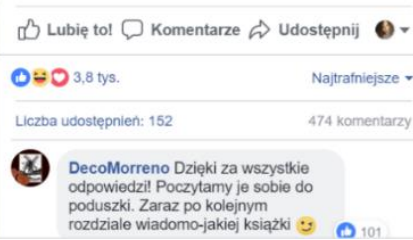

Źródło: Facebook, https://bit.ly/1UFCCDx (dostęp: 13.06.2019).

Łódzka agencja marketingowa Bluerank niedawno, bo w maju 2019 roku, zdobyła prestiżową nagrodę European Search Awards za kampanię realizowaną razem z marką Euroloan. Kampania została wyróżniona w dwóch kategoriach: Best Use of Social Media in a Search 
Campaign oraz Best Integrated Campaign. W ramach działań marketingowych agencja postanowiła podkreślić akcent pochodzenia marki (Finlandia) i zaproponowała stworzenie tzw. Brand heroes marki. W wyniku tych działań powstał:

1. Rzeczowy Matti: finanse/porady,

2. Bystry Jussi: ciekawostki,

3. Luźny Timo: lifestyle/wakacje/rozrywka,

4. Roztropny Seppo: adwokat klienta/nowe produkty.

Wymienione postacie zostały przypisane do określonych linii tematycznych w komunikacji marketingowej oraz pojawiły się w dystrybuowanych materiałach. Podstawą do rozpoczęcia działań integrujących kanały marketingowe było zmierzenie przez agencję wpływu kampanii ATL-owych (działania reklamowe skierowane do odbiorcy masowego [Poradnik Przedsiębiorcy, 2019] na zasięgi osiągane na Facebooku. Do dzisiaj bohaterowie marki pojawiają się w różnorodnych kanałach zarówno online i offline (rysunek 4).

Rysunek 4. Euroloan brand heroes
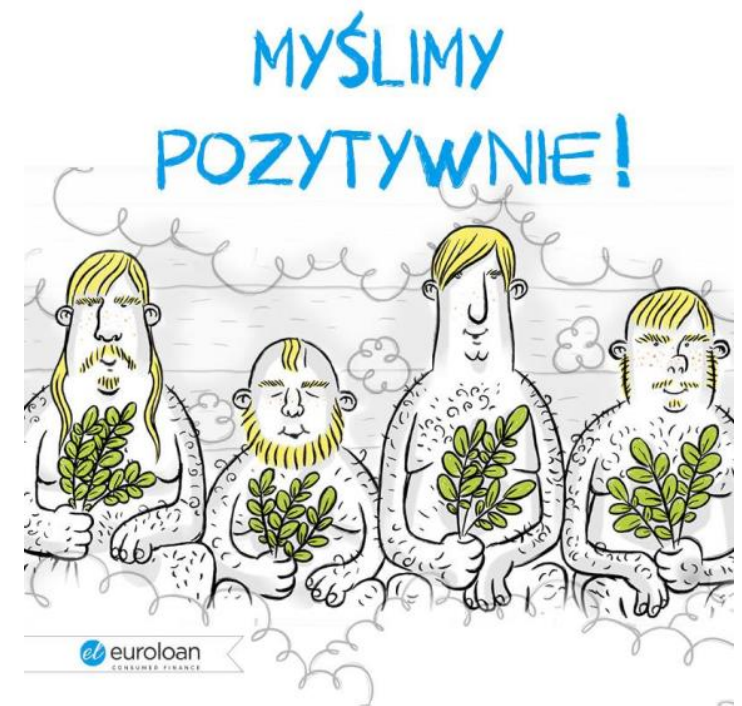

Żródło: Facebook, Euroloan, https://bit.ly/2tD0qC5 (dostęp: 13.06.2019).

Niewątpliwie kreatywność leży u podłoża każdej szeroko komentowanej kampanii. Nowe spojrzenie na znane wydarzenia pozwalają markom wyróżnić się z natłoku docierających do klienta komunikatów. Wywołują emocje, a tym samym i pozostają dłużej w jego pamięci. Angażują i zachęcają do interakcji z marką. 


\section{Cel i metodyka badań}

By skonfrontować zebrany materiał teoretyczny $\mathrm{z}$ realiami pracy branży marketingowej przeprowadzono dodatkowe badania. Ich celem było poznanie wpływu wykorzystania kreatywności w procesie tworzenia kampanii marketingowych. Pod uwagę wzięto również efektywność takich kreacji. W przeprowadzonym badaniu zastosowano jakościową metodę zbierania informacji, jaką jest indywidualny wywiad kwestionariuszowy. Zastosowanie tej metody pozwoliło na zweryfikowanie zebranego materiału teoretycznego dotyczącego kreatywności i działań marketingowych w obszarze social mediów. Na podstawie kryterium doświadczenia zawodowego i osiągnięć w branży przeprowadzono pogłębione rozmowy $\mathrm{z}$ osobami na co dzień pracującymi w tym środowisku. Spotkania odbyły się na początku czerwca 2019 roku i pozwoliły określić w jakim stopniu kreatywność wpływa na kreację i efektywność kampanii marketingowych.

W badaniu zastosowano celowy dobór próby i zaproszono trzech przedstawicieli branży interaktywnej, którzy na co dzień zajmują się projektowaniem komunikacji marketingowej dla wielu marek. Bazując na swoim doświadczeniu zawodowym zaproszeni do badania eksperci przedstawili swoją opinię na temat znaczenia wykorzystania kreatywności $\mathrm{w}$ procesie projektowania strategii komunikacyjnej $\mathrm{w}$ mediach społecznościowych. Rozmówcy to osoby z co najmniej 5-letnim stażem zawodowym, reprezentujący kolejno takie agencje, jak: Bluerank, 38Digital oraz OSOM Studio.

Wszyscy trzej zaproszeni do wywiadu eksperci otrzymali taki sam zestaw dwunastu otwartych pytań dotyczących wskaźników efektywności kampanii, wykorzystywanych w codziennej pracy narzędzi i znaczenia kreatywności w działaniach marketingowych.

\section{Kreatywność w dzialaniach marketingowych - opinie eksperckie}

Przeprowadzone z ekspertami wywiady pozwoliły zrealizować cel badania, jakim było uzyskanie odpowiedzi na pytanie o wpływ kreatywności na tworzenie efektywnej komunikacji marketingowej. W wielu omawianych obszarach respondenci byli zgodni. Jak twierdzą kreatywność jest ważnym, lecz nie podstawowym, czynnikiem prowadzącym do sukcesu kampanii. 
Adam Dębski (Bluerank) na początku rozmowy podkreślił, że efektywność danej kampanii można mierzyć w odniesieniu do określonego wcześniej celu, jaki ma zostać osiągnięty. W zależności od działań na jakie nastawiona jest marka, można mierzyć: efektywność obsługi klienta, wzrost sprzedaży, czy uzyskane w mediach społecznościowych zasięgi. Jednakże na te wskaźniki wpływa również wiele dodatkowych składowych, jak grupa docelowa, stosowane komunikaty, czy platformy, na których znajdują się potencjalni klienci. Te informacje stanowią także wyjście do planowania strategii komunikacyjnej. Dopiero zebrana wiedza pozwoli wyznaczyć kierunek poszukiwania kreatywnych pomysłów na przyciągnięcie uwagi klienta. Dla A. Dębskiego kreatywność to przede wszystkim odwaga do podejmowania nieoczywistych decyzji i próbowania nieszablonowych podejść do danego zagadnienia. Zachowuje on przy tym jednak pewną ostrożność i stawia raczej na pomysły ewolucyjne, acz wnoszące dla odbiorcy powiew świeżości. Jeśli razem ze swoim zespołem znajdzie kreatywne pomysły, które co więcej mają szansę zaangażować użytkownika, to chętnie implementuje je w komunikacji marketingowej marki. W samych mediach społecznościowych niewątpliwie Adam Dębski upatruje duży potencjał dla komunikacji bezpośredniej z odbiorcą. Podaje przykłady komunikatorów, jak Messenger, czy Whatsapp, które mają wciąż duże pole działania dla rozwoju, a ich skuteczność ocenia zdecydowanie wyżej niż w przypadku newsletterów.

Podobnie jak A. Dębski, Hubert Walkowicz (38Digital), mówiąc o efektywności kampanii najpierw pyta o cele, jakie zostały ustalone z klientem agencji. Dopiero wtedy może ocenić, czy to co wypracował razem z zespołem, jest także tym czego oczekiwał klient i pozwoli zakwalifikować kampanię do udanych. Z własnego doświadczenia wie jednak, że są również wskaźniki, które, choć nie przekładają się bezpośrednio na realizację ustalonego celu, służą często pozytywnie wizerunkowi jego pracy. Wymienia tu np. wzrost liczby osób lubiących profil marki. Co ciekawe, H. Walkowicz upatruje szans rozwoju mediów społecznościowych w rozwiązaniach, które pozwolą na jednoczesną ,konsumpcję" wiadomości z portali i wykonywanie innych czynności. Sądzi, że takie zmiany mogą zrewolucjonizować dotychczasowe podejście do mediów społecznościowych. Zauważa jednocześnie, że społeczeństwo coraz częściej zaczyna dostrzegać jednak negatywne strony internetowych społeczności i przypuszcza, że w ciągu najbliższych lat wielu młodych ludzi, na bazie zebranych przez lata doświadczeń, zacznie podejmować świadomą decyzję, o odsunięciu się od świata social mediów. Na kreatywność patrzy natomiast jak na ,umiejętność kreowania rozwiązań w ramach zastanych ograniczeń". Jest to dla niego zatem zdolność 
poszukiwania rozwiązań. Dlatego też zgadza się z opisanym przez R. Luecke i R. Katza podejściem, że wiedza determinuje możliwości twórczego myślenia u ludzi [Luecke, Katz, 2005: 124]. Jak sam stwierdził „wiedza daje mu świadomość liczby możliwości". Sam stara się inspirować w swojej pracy informacjami z zupełnie innych branż. Szuka między nimi połączeń, które będzie mógł wykorzystać podczas tworzenia kampanii.

Angelika Żyżniewska (OSOM Studio) przewiduje natomiast, że w działaniach marek dalej rozwijany będzie trend komunikacji „tu i teraz". Powołuje się tu na stale rosnące zainteresowanie merytorycznymi webinariami prowadzonymi zarówno na Facebooku, jak i na Instagramie. Wskazuje także na potrzebę weryfikacji z zapoznanymi przez odbiorcę treściami udostępnianymi przez markę. Same polubienia, czy otworzenia linku nie są według niej miarodajne. Nieznany jest bowiem czas poświęcony na „konsumpcję” treści. Możliwe zatem jest, że była to kilkusekundowa odsłona strony, która nie zostanie przez konsumenta w ogóle zapamiętana. Po części również, dlatego A. Żyżniewska największy potencjał upatruje w kreatywnym łączeniu działań digitalowych z tymi prowadzonymi w środowisku offline. Radzi jednak, by uważać na pomysły balansujące między kreatywnością, a kontrowersją. Przytacza przykłady takich marek jak: PGE, Żytnia, czy Tiger, które poprzez zbyt kontrowersyjne kreacje straciły na swoim wizerunku. Dlatego podpowiada, by koncepty kreatywne były uprzednio poparte dokładnymi analizami grupy docelowej, bo czasem lepsze efekty przyniesie znany już schemat postu niż nieszablonowy, oryginalny koncept.

Analizując wypowiedzi respondentów pewnym jest, że praca nad każdą kampanią marketingową musi rozpocząć się od wyznaczenia celów. W zależności od wybranego przez klienta kierunku, agencja będzie dobierała odpowiednie działania i wskaźniki monitorowania postępów, jak np. poziom obsługi klienta (czas odpowiedzi i wskaźnik reakcji), wzrost sentymentu wobec marki, zasięg, konwersja do zakupu, wartość sprzedaży i zaangażowanie społeczności.

Znajomość celu, jaki kampania ma realizować stanowi punkt wyjścia do rozpoczęcia pracy kreatywnej i poszukiwania oryginalnych sposobów komunikacji marki z konsumentami. Każdy z badanych podchodzi jednak do zagadnienia kreatywności nieco inaczej. Dla Huberta Walkowicza jest to przede wszystkim pojęcie tożsame z umiejętnością rozwiązywania problemów lub poszukiwania, jak mówi „nowych rozwiązań w ramach istniejących ograniczeń". Adam Dębski dodatkowo wspomina o odwadze, która towarzyszy mu przy podejmowaniu często nieoczywistych decyzji. Dla Angeliki Żyżniewskiej kreatywność jest natomiast działaniem wymuszającym dostrzegania nowych zastosowań dobrze znanych już narzędzi lub nowych metod postępowania w znanych już 
sytuacjach. Dla badanych kreatywność łączy się zatem z odkrywaniem, eksperymentowaniem, ale i wnikliwą obserwacją, by dostrzec nowe szanse. Doświadczenie pracy w agencji pokazało, że kreatywność nie jest podstawowym warunkiem skutecznej komunikacji. Od oryginalnego konceptu liczy się bardziej odpowiedni research. Zbadanie, gdzie znajdują się potencjalni klienci i wybór najefektywniejszych kanałów społecznościowych do dystrybucji przygotowanej treści. Znaczenie ma także format udostępnianych materiałów. Badani przyznają, że w ostatnim czasie najskuteczniejsze pod względem liczby wyświetleń, czy wzbudzanego zaangażowania są krótkie (nawet jednosekundowe) treści video. H. Walkowicz i A. Żyżniewska dostrzegają szczególny potencjał w Instagram Stories. To tam w nadchodzącym czasie upatrują pola do intensyfikacji działań marketingowych.

Badani wskazują, że poszukiwanie oryginalnych koncepcji komunikacji stanowi kolejny krok planowania strategii komunikacji marki po uprzednim zbudowaniu podłoża teoretycznego i zgromadzeniu potrzebnych informacji. Dopiero w ramach wybranych kanałów i dostępnych narzędzi poszukiwane są sposoby zaintrygowania odbiorcy. To do czego dążą respondenci to znalezienie niewielkich udoskonaleń, prostych, acz zaskakujących rozwiązań, które będą mogły jednak przynieść konkretne rezultaty. Jak twierdzi A. Dębski, czasem jest to po prostu otwartość na nowe technologie, których zastosowanie spowoduje spektakularny efekt. Niekiedy jest to kwestia spostrzegawczości, wyczucia chwili i odpowiedniego komentarza. Czasem jednak proces poszukiwania kreatywnych rozwiązań jest długi. Interesującą, a zarazem niepokojącą obserwacją wynikającą z wypowiedzi rozmówców jest fakt, że podczas sesji kreatywnych, w większości przypadków, wykorzystują oni jedynie metodę burzy mózgów. Wydawać by się mogło, że w zawodach wymagających częstej pracy twórczej świadomość dostępnych metod pobudzających kreatywne myślenie powinna być zdecydowanie szersza.

Respondenci zapytani o efektywność kreatywnych koncepcji stosowanych w komunikacji marketingowej nie potrafili udzielić jednoznacznej odpowiedzi. H. Walkowicz podkreśla, że zdarzają się sytuację, gdy kreatywne rozwiązania nie przechodzą egzekucji biznesowej, gdyż efekt działań, mimo że pozytywny, może być niewspółmierny z kosztami jakie trzeba by było ponieść, by go osiągnąć. A jak mówi „kreatywność jest czasochłonna". W agencji, która codziennie pracuje nad projektami komunikacji kilku marek szukanie spektakularnych pomysłów dla każdej $\mathrm{z}$ nich jest niewykonalne. Jednakże działanie na nieco mniejszą skalę i poszukiwanie atrybutów, które wyróżnią dany profil społecznościowy i stworzą indywidualny charakter marki jest konieczne, by przyciągnąć uwagę internauty i zbudować na fanpage aktywną społeczność. 
Co ciekawe, w wypowiedziach respondentów zapytanych o marki, które ich zdaniem prowadzą kreatywną komunikację wszyscy wskazali markę Żywiec ze szczególnym wyróżnieniem materiałów copywriterskich rozpoczynających się literą „Ż”. Zarówno Hubert Walkowicz, jak i Angelika Żyżniewska wyróżnili również kampanię Kurki Wolnej. W zestawieniu pochwały zebrało również Allegro, Lego i Krakus.

\section{Zakończenie}

Jak wynika z licznych raportów, intensywny rozwój mediów społecznościowych w ciągu ostatniego dziesięciolecia sprawił, że wiele firm zaczęło dostrzegać w tym kanale potencjał marketingowy. Podejście to wzmacniali twórcy portali społecznościowych, oferując rozwiązania i możliwości reklamowe dla biznesu. Dziś w sieciach społecznościowych zarejestrowanych jest już miliony kont firmowych budujących swoją społeczność odbiorców. Konkurencja takich kont jest jednak tak duża, że coraz trudniej przyciągnąć uwagę internauty. Dodatkowo największe platformy społecznościowe, jak chociażby Facebook, zaczynają rezygnować z organicznie generowanych zasięgów udostępnianych treści komercyjnych na rzecz zwiększenia wydatków przedsiębiorstw na działania promocyjne. Takie zabiegi sprawiają, że dystrybuowane tam treści muszą być coraz bardziej przemyślane, spójne z ogólną koncepcją strategii marketingowej, ale także zachęcające obserwatora do zaangażowania. Niezbędne staje się też prowadzenie zintegrowanej komunikacji marketingowej zarówno w przestrzeni internetowej, jak i w mediach tradycyjnych. Działania te powinny się bowiem uzupełniać, co zdecydowanie zwiększa skuteczność oddziaływania takiego przekazu na odbiorcę. W powyższej pracy przybliżono specyfikę trzech największych na świecie kanałów społecznościowych: Facebook, Instagram i YouTube. Omówione zostały także podstawowe narzędzia marketingowe oferowane przez każdą z tych platform.

W wyróżnieniu komunikatów marki pomóc może przełamanie schematów i przyzwyczajeń internautów. Ich uwagę przyciągną treści nietypowe. To w kreatywności upatrywane są szanse na zwiększenie skuteczności kampanii marketingowych realizowanych w mediach społecznościowych. Niezwykle ważne jest także zwrócenie uwagi na znaczenie wiedzy w procesie kreatywnym. To ona pozwala dostrzec nowe możliwości, a następnie wdrożyć nowe rozwiązania w życie. W działaniach marketingowych w social mediach szczególne znaczenie ma świadomość grupy docelowej, do 
której kierowane są komunikaty. Znajomość ich zainteresowań i stylu komunikacji na linii marka - klient pozwolą określić przewidywany poziom akceptacji kreatywnych rozwiązań marki.

Aby zrealizować cel pracy, jakim było zweryfikowanie, czy kreatywność stanowi istotny czynnik wpływający na efektywność kampanii marketingowych o opinię zapytano ekspertów. Byli to praktycy, z co najmniej 5-letnim doświadczeniem zawodowym, na co dzień pracujący w cenionych łódzkich agencjach marketingowych odpowiedzialni za tworzenie strategii komunikacji marek w mediach społecznościowych $\mathrm{i}$ ich realizację. W badaniu IDI (in depth interview) udział wzięli: Adam Dębski (Bluerank), Hubert Walkowicz (38Digital) oraz Angelika Żyżniewska (OSOM Studio). Przeprowadzone pogłębione wywiady pozwoliły osiągnąć cel pracy, potwierdzając istotność wykorzystania kreatywności w działaniach marketingowych. Respondenci zwracali jednak uwagę, że kreatywność jest dla nich metodą na rozwiązywanie problemów, działaniami często bardziej ewolucyjnymi, wynikającymi z wnikliwej obserwacji, niż całkowicie zaskakującymi, rewolucyjnymi rozwiązaniami. Każdy z badanych podkreślił, że na efektywność kampanii przede wszystkim składa się znajomość celu i plan działań, jakie pozwolą go osiągnąć. Będą one bowiem inne w zależności od tego, czy marka będzie chciała zwiększyć świadomość konsumentów, angażować zgromadzoną na profilu społeczność, czy usprawnić czas obsługi klienta. Praca kreatywna może zatem nastąpić na podstawie zgromadzonej wiedzy o marce i jej odbiorcach. Dopiero takie podejście pozwoli zagwarantować sukces kampanii.

\section{BIBLIOGRAFIA}

Ambile T.M. (1998), How to Kill Creativity, „Harvard Business Review”, no 5, s. 76-87.

Bdoń E., Marketing relacji - co to jest $i$ jak go stosować?, Freshmail, https://freshmail.pl/blog/marketing-relacji-co-jest-jak-go-stosowac/ (dostęp: 12.02.2019).

Bonek T., Smaga M. (2013), Biznes na Facebooku i nie tylko. Praktyczny poradnik o promocji w mediach spotecznościowych, Wolters Kluwer, Warszawa.

Chaykowski K. (2015), Number Of Facebook Business Pages Climbs To 50 Million With New Messaging Tools, https://www.forbes.com/sites/kathleenchaykowski/ 2015/12/08/facebook-business-pages-climb-to-50-million-with-new-messaging-tools/ \#18b4 cf36991c (dostęp: 29.01.2019).

Dane Instagramu, https://business.instagram.com/?locale=pl_PL (dostęp: 26.01.2019).

Facebook Ikea, https://bit.ly/2KuTuAs (dostęp: 13.06.2019).

Facebook Ikea, https://bit.ly/2N4OfWE (dostęp: 13.06.2019).

Facebook newsroom, https://newsroom.fb.com/company-info/ (dostęp: 28.01.2019).

Facebook, Euroloan, https://bit.ly/2tD0qC5 (dostęp: 13.06.2019). 
Facebook, https://bit.ly/1UFCCDx (dostęp: 13.06.2019).

Feedink.com, Snajperska precyzja w targetowaniu reklamy na Facebooku, https://feedink.com/pl/target-facebook-ads-like-pro/ (dostęp: 12.04.2019).

Instagram business, https://business.instagram.com/getting-started (dostęp: 28.01.2019).

Kallas P., Top 15 Most Popular Social Networking Sites and Apps, https://www.dreamgrow.com/top-15-most-popular-social-networking-sites/ (dostęp: 29.01.2019).

Kaznowski D. (2016), E-marketing. Współczesne trendy. Pakiet startowy, Wydawnictwo Naukowe PWN, Warszawa.

Kuchta M. (2017), Real Time Marketing $w$ wykonaniu IKEA. Jak na aktualne wydarzenia reagowała marka?, https://socialpress.p1/2017/03/real-time-marketing-w-wykonaniuikea-jak-na-aktualne-wydarzenia-reagowala-marka (dostęp: 13.06.2019).

Leśniewska A. (2006), Reklama internetowa, Wydawnictwo Onepress, Gliwice.

Luecke R., Katz R. (2005), Zarzadzanie kreatywnościa i innowacja, MT Biznes, Konstancin-Jeziorna.

Mediakix Team, How much time we spend on social media, https://mediakix.com/blog/howmuch-time-is-spent-on-social-media-lifetime/\#gs.zah2iPs (dostęp: 28.01.2019).

Mercer C., Traditional vs. Online Marketing. The Real Value of Your Online Marketing Efforts, https://seriouslysimplemarketing.com/traditional-vs-online-marketing/ (dostęp: 29.01.2019).

Peterson T. (2017), How Facebook's, Instagram's and Snapchat's audience size estimates compare, https://marketingland.com/facebooks-instagrams-snapchats-audience-sizeestimates-compare-223893 (dostęp: 29.01.2019).

Pizło W., Marketing relacji - koncepcja $i$ kierunki rozwoju, http://www.wne.sggw.pl/czasopisma/pdf/EIOGZ_2008_nr69_s89.pdf (dostęp: 1.02.2019).

Poradnik Przedsiębiorcy (2019), Tradycyjny podział na ATL i BTL a marketing XXI wieku, https://poradnikprzedsiebiorcy.pl/-tradycyjny-podzial-na-atl-i-btl-a-marketing-xxiwieku (dostęp: 25.06.2019).

Sadowski M. (2013), Rewolucja social media, Wydawnictwo Helion, Gliwice.

Sagan A. (2013), Symbolika produktu w systemie komunikacji marketingowej. Studium teoretyczno-metodologiczne, Wydawnictwo Akademii Ekonomicznej w Krakowie, Kraków.

WYBOROWA Project 30/90, https://www.youtube.com/watch?v=KKMO1xQ-k68 (dostęp: 25.05.2019).

YouTube for press, https://www.youtube.com/intl/en-GB/yt/about/press/ (dostęp: 28.01.2019).

YouTube for press, https://www.youtube.com/intl/en-GB/yt/about/press/ (dostęp: 18.01.2019).

YouTube for press, https://www.youtube.com/intl/en-GB/yt/about/press/ (dostęp: 27.07.2019).

Zephoria Inc, Top 01 Twitter statistic, https://zephoria.com/twitter-statistics-top-ten/ (dostęp: 28.01.2019).

Żukowski M. (2016), Twoja firma w social mediach. Podręcznik marketingu internetowego dla matych $i$ średnich przedsiębiorstw, Wydawnictwo Helion, Gliwice.

http://sjp.pwn.pl/slowniki/media\%20spo\%C5\%82eczno\%C5\%9Bciowe.html (dostęp: 20.01.2019).

https://pl.wikipedia.org/wiki/Toplayer (dostęp: 29.01.2019). 


\section{USE OF CREATIVITY IN SOCIAL MEDIA MARKETING COMMUNICATION}

\section{SUMMARY}

The purpose of the chapter was to show the impact of the use of creativity in marketing communication of brands in social media. It was realized through the analysis of selected examples of campaigns carried out in social media, distinguished by originality, the high interest of recipients and a positive assessment of experts.

Keywords: marketing communication, creativity, brand, social media, marketing, Facebook, Instagram. 